\title{
Sediment Chemistry and Meiofauna from the Northern Gulf of Mexico Continental Shelf
}

\author{
Ceil C. Martinec, ${ }^{1}$ Jonathan M. Miller, ${ }^{1}$ Nathan K. Barron, ${ }^{1}$ Rui Tao, ${ }^{1}$ Kewei Yu, \\ Paul M. Stewart, ${ }^{1}$ Alfred C. Nichols, ${ }^{2}$ David A. Steffy, ${ }^{2}$ and Stephen C. Landers ${ }^{1}$ \\ ${ }^{1}$ Department of Biological and Environmental Sciences, Troy University, Troy, AL 36082, USA \\ ${ }^{2}$ Department of Physical and Earth Sciences, Jacksonville State University, Jacksonville, AL 36265, USA
}

Correspondence should be addressed to Stephen C. Landers; slanders@troy.edu

Received 19 June 2014; Revised 8 September 2014; Accepted 9 September 2014; Published 1 October 2014

Academic Editor: Eric Achterberg

\begin{abstract}
Copyright (C) 2014 Ceil C. Martinec et al. This is an open access article distributed under the Creative Commons Attribution License, which permits unrestricted use, distribution, and reproduction in any medium, provided the original work is properly cited.
\end{abstract}

\begin{abstract}
This study examined sediment chemistry, granulometry, and meiofauna on the northern Gulf of Mexico continental shelf from central Louisiana to Apalachicola, Florida. Sediment samples were collected in October/November 2012 with a Shipek grab sampler from 26 locations (extending from $28^{\circ} 18^{\prime} 46.079^{\prime \prime} \mathrm{N}, 91^{\circ} 10^{\prime} 44.471^{\prime \prime} \mathrm{W}$ to $29^{\circ} 3^{\prime} 48.383^{\prime \prime} \mathrm{N}, 85^{\circ} 28^{\prime} 25.679^{\prime \prime} \mathrm{W}$ ) at depths ranging from 49 to $361 \mathrm{~m}$. Sediment analysis revealed two distinct profiles to the east and west of the Mississippi River Delta at approximately $88^{\circ} 30^{\prime} \mathrm{W}$. The concentrations of silt + clay, organic carbon, $\mathrm{Ba}, \mathrm{Cr}, \mathrm{Cu}, \mathrm{Fe}, \mathrm{Ni}, \mathrm{Pb}, \mathrm{V}$, and $\mathrm{Zn}$ were higher in western sites and positively correlated with $\mathrm{Al}$ concentrations. Eastern sites contained sandier sediments with lower organic carbon concentrations and higher $\mathrm{Sr}$ and $\mathrm{Ca}$ concentrations. Nematode densities were higher at western sites and positively correlated with $\mathrm{Al}, \mathrm{Cr}, \mathrm{Cu}, \mathrm{Fe}$, $\mathrm{Ni}, \mathrm{Pb}, \mathrm{Zn}$, silt + clay, and organic carbon concentrations. Copepod densities correlated with very coarse + coarse sand, exhibiting higher densities at eastern sites. PAH concentrations were relatively low, with all sites having $<1700 \mu \mathrm{g} / \mathrm{kg}$ total PAHs. This study has revealed two distinct sediment profiles in the eastern and western zones of the study, which appear to influence the nematode and copepod densities.
\end{abstract}

\section{Introduction}

The Gulf of Mexico (GOM) Deepwater Horizon Oil Spill (DHOS) of 2010 was the largest oil spill in the United States' history, releasing 4.6 million barrels of oil (731 million liters) [1]. Heavy oiling occurred on the coastal areas of Louisiana to Florida, while deep-sea sediments may have been affected by the oil on the sea floor [1-3]. More recently (July 2013) another smaller event, the Hercules-256 natural gas platform blowout, occurred less than 100 kilometers from the coast of Louisiana [4]. In March of 2014, approximately 4,000 barrels (635,949 liters) of additional oil were released into Galveston Bay [5].

In light of recent and ongoing accidents involving human activities in the GOM, there is a growing need for the documentation of the overall condition of this ecosystem. Efforts to catalog the health of US coastal ecosystems began around the 1960s [2] and many recent studies have focused on deep-sea benthic communities $[1,6,7]$. However, few studies have examined the benthos of the GOM continental shelf, though this habitat contains microscopic communities (meiofauna) that serve as the base of an immense food chain. These meiofauna are important benthic components that are often used as indicators in pollution studies [8].

This study examines continental shelf sediment chemistry and general meiofauna trends near the $100 \mathrm{~m}$ isobath in the northern GOM. This research expands on a preliminary report by Landers et al. [9], by examining meiofauna and sediment relationships over a broad area of the northern GOM continental shelf.

\section{Methods}

2.1. Sample Collection. Sediment samples were collected using a Shipek grab sampler aboard the National Oceanic and Atmospheric Administration (NOAA) ship Gordon 
Gunter along the northern GOM continental shelf and slope in October and November of 2012 (Figure 1). Sample depths ranged from 49 to $361 \mathrm{~m}$ (mean $=120 \mathrm{~m}$ ). One hundred and thirty sediment samples were obtained from 26 sites (three for meiofauna analysis and two for sediment analysis per site) (Table 1). Sediment grabs were collected to a $10.2 \mathrm{~cm}$ depth (bite depth of Shipek grab sampler) and then subcored three times to a $5 \mathrm{~cm}$ depth with a coring tube $\left(15.19 \mathrm{~cm}^{2}\right.$ area). These nested subcores targeted the subsurface meiofauna, since the Shipek grab disturbs the fine flocculent surface of the sediment. The three subcores were preserved in 5\% formalin (final concentration) for meiofauna analysis. Two additional samples were taken from the remaining sediment in the Shipek grab for PAH, trace metal, organic carbon, and granulometric analysis. Global Positioning System coordinates, water temperature, depth, salinity, and dissolved oxygen were recorded by NOAA at each site. Figure 1 was created in ArcGIS 10.2.2. The ocean basemap was downloaded from http://www.arcgis.com/home/item.html?id=9a12467dld574a 9c836607821fd7fe04 on September 10, 2014. The basemap was compiled by Environmental Systems Research Institute and other contributors. Bathymetry data were also obtained on September 10, 2014, from the United States Geological Survey's Coastal and Marine Geology Program at http://www.arcgis.com/home/item.html?id=9a12467dld574a 9c836607821fd7fe04.

2.2. Meiofauna Analysis. Sediment samples were sieved in the laboratory with a $333 \mu \mathrm{m}$ presieve, followed by 63 and $45 \mu \mathrm{m}$ sieves. Ludox centrifugation was used to extract the meiofauna from the sediment $[10,11]$. Meiofauna were then stained with rose bengal, counted, and identified to major group under a stereomicroscope at Troy University according to Higgins and Thiel [12]. Though the 45 and $63 \mu \mathrm{m}$ samples were counted separately to allow for comparisons with past studies that used one of the two sieves, the data were combined in order to report density values representing total meiofauna larger than $45 \mu \mathrm{m}$.

2.3. PAH Analysis. Sediment PAHs were determined at Troy University using Soxhlet extraction with dimeth-ylene chloride following EPA method 3540C [13]. PAH concentrations were analyzed using a Shimadzu GC/MS (GC-2010-mass spectrometer) calibrated for petroleum hydrocarbon analysis. The precision of the instrument was $\pm 1 \%$. Each sample was divided into three subsamples consisting of two replicates and a spiked subsample. Certified reference standards were purchased from Absolute Standards, Inc. for $27 \mathrm{PAH}$ calibrations. Each sample was analyzed for the following 27 PAHs (16 EPA priority PAHs in italics): naphthalene, 2-methylnaphthalene, 1-methylnaphthalene, biphenyl, 2,6-dimethylnaphthalene, acenaphthylene, acenaphthene, dibenzofuran, 2,3,5-trimethylnaphthalene, fluorene, dibenzothiophene, phenanthrene, anthracene, carbazole, 1-methylphenanthrene, fluoranthene, pyrene, chrysene, benzo(a)anthracene, benzo(b)fluoranthene, benzo(k)fluoranthene, benzo(e)pyrene, benzo(a)pyrene, perylene, dibenzo(a,h)anthracene, benzo $(g, h, i)$ perylene, and indeno $(1,2,3-c d)$ pyrene.
TABLE 1: Latitude, longitude, and grab depth at each sampling site.

\begin{tabular}{|c|c|c|c|}
\hline Site & Latitude $\left({ }^{\circ} \mathrm{N}\right)$ & Longitude $\left({ }^{\circ} \mathrm{W}\right)$ & Depth (m) \\
\hline 73 & $28^{\circ} 18^{\prime} 46.079^{\prime \prime}$ & $91^{\circ} 10^{\prime} 44.471^{\prime \prime}$ & 65.2 \\
\hline 75 & $28^{\circ} 7^{\prime} 28.488^{\prime \prime}$ & $90^{\circ} 53^{\prime} 37.319^{\prime \prime}$ & 113.2 \\
\hline 77 & $28^{\circ} 22^{\prime} 7.499^{\prime \prime}$ & $90^{\circ} 30^{\prime} 44.064^{\prime \prime}$ & 49.3 \\
\hline 78 & $28^{\circ} 11^{\prime} 34.943^{\prime \prime}$ & $90^{\circ} 18^{\prime} 55.368^{\prime \prime}$ & 128.1 \\
\hline 80 & $28^{\circ} 49^{\prime} 22.764^{\prime \prime}$ & $89^{\circ} 42^{\prime} 38.627^{\prime \prime}$ & 69.7 \\
\hline 81 & $28^{\circ} 47^{\prime} 0.671^{\prime \prime}$ & $89^{\circ} 33^{\prime} 40.392^{\prime \prime}$ & 87.5 \\
\hline 82 & $28^{\circ} 37^{\prime} 59.340^{\prime \prime}$ & $89^{\circ} 13^{\prime} 16.319^{\prime \prime}$ & 242.0 \\
\hline 83 & $28^{\circ} 46^{\prime} 27.191^{\prime \prime}$ & $89^{\circ} 4^{\prime} 30.180^{\prime \prime}$ & 360.8 \\
\hline 84 & $28^{\circ} 58^{\prime} 51.024^{\prime \prime}$ & $88^{\circ} 59^{\prime} 56.472^{\prime \prime}$ & 84.8 \\
\hline 85 & $29^{\circ} 7^{\prime} 56.711^{\prime \prime}$ & $88^{\circ} 42^{\prime} 27.467^{\prime \prime}$ & 86.1 \\
\hline 86 & $29^{\circ} 17^{\prime} 21.156^{\prime \prime}$ & $88^{\circ} 33^{\prime} 21.239^{\prime \prime}$ & 65.7 \\
\hline 87 & $29^{\circ} 21^{\prime} 58.428^{\prime \prime}$ & $88^{\circ} 28^{\prime} 27.299^{\prime \prime}$ & 58.8 \\
\hline 89 & $29^{\circ} 24^{\prime} 30.168^{\prime \prime}$ & $87^{\circ} 51^{\prime} 21.491^{\prime \prime}$ & 74.4 \\
\hline 90 & $29^{\circ} 28^{\prime} 58.008^{\prime \prime}$ & $87^{\circ} 27^{\prime} 53.532^{\prime \prime}$ & 85.3 \\
\hline 91 & $29^{\circ} 38^{\prime} 23.063^{\prime \prime}$ & $87^{\circ} 24^{\prime} 10.871^{\prime \prime}$ & 65.3 \\
\hline 97 & $29^{\circ} 56^{\prime} 41.135^{\prime \prime}$ & $86^{\circ} 55^{\prime} 4.584^{\prime \prime}$ & 150.9 \\
\hline 98 & $29^{\circ} 55^{\prime} 51.131^{\prime \prime}$ & $86^{\circ} 31^{\prime} 25.752^{\prime \prime}$ & 79.8 \\
\hline 99 & $29^{\circ} 45^{\prime} 16.200^{\prime \prime}$ & $86^{\circ} 22^{\prime} 37.128^{\prime \prime}$ & 102.3 \\
\hline 102 & $29^{\circ} 41^{\prime} 0.348^{\prime \prime}$ & $86^{\circ} 22^{\prime} 9.659^{\prime \prime}$ & 114.1 \\
\hline 103 & $29^{\circ} 32^{\prime} 52.655^{\prime \prime}$ & $86^{\circ} 16^{\prime} 42.959^{\prime \prime}$ & 123.8 \\
\hline 104 & $29^{\circ} 31^{\prime} 21.756^{\prime \prime}$ & $86^{\circ} 6^{\prime} 38.448^{\prime \prime}$ & 81.3 \\
\hline 111 & $29^{\circ} 19^{\prime} 0.732^{\prime \prime}$ & $85^{\circ} 44^{\prime} 39.408^{\prime \prime}$ & 60.9 \\
\hline 112 & $29^{\circ} 3^{\prime} 48.383^{\prime \prime}$ & $85^{\circ} 28^{\prime} 25.679^{\prime \prime}$ & 61.5 \\
\hline 113 & $28^{\circ} 48^{\prime} 17.604^{\prime \prime}$ & $85^{\circ} 47^{\prime} 10.608^{\prime \prime}$ & 220.8 \\
\hline 161 & $28^{\circ} 35^{\prime} 47.472^{\prime \prime}$ & $85^{\circ} 46^{\prime} 35.399^{\prime \prime}$ & 259.4 \\
\hline 162 & $28^{\circ} 44^{\prime} 45.167^{\prime \prime}$ & $85^{\circ} 52^{\prime} 5.015^{\prime \prime}$ & 259.2 \\
\hline
\end{tabular}

2.4. Trace Metal and Organic Carbon Analysis. Samples were analyzed for 31 metals and organic carbon content at the Central Analytical Instruments Research Laboratory of Louisiana State University. Metal concentrations were analyzed using an Inductively Coupled Plasma Analyzer (Varian Vista MPX ICP-OES) following EPA method 200.7 [14]. Inductively coupled plasma calibration standards were prepared in the $\mathrm{HCl}+\mathrm{HNO}_{3}$ acid matrix, similar to the sample matrix. Sediment samples were digested at $120^{\circ} \mathrm{C}$ for 30 minutes using trace metal grade nitric and hydrochloric acids. Instrument calibration was verified using a 2 nd source multielement standard purchased from Exaxol Chemical Corporation. The analytical precision of the instrument was $\pm 3 \%$. Percent recovery of metal was determined by spiking the sample with the known amount of concentration. To determine the amount of organic carbon, soil samples were initially treated with dilute $\mathrm{HCl}$ to remove inorganic carbonates followed by total carbon determination by dry combustion at $980^{\circ} \mathrm{C}$ using a TruSpec CN analyzer (LECO, St. Joseph, MI). The CN analyzer was calibrated using NIST soil standards. The precision of the instrument was $\pm 2 \%$ and the protocol followed EPA method 9060 [15].

2.5. Granulometric Analysis. Granulometry was determined at Jacksonville State University. Sediment samples were dried 


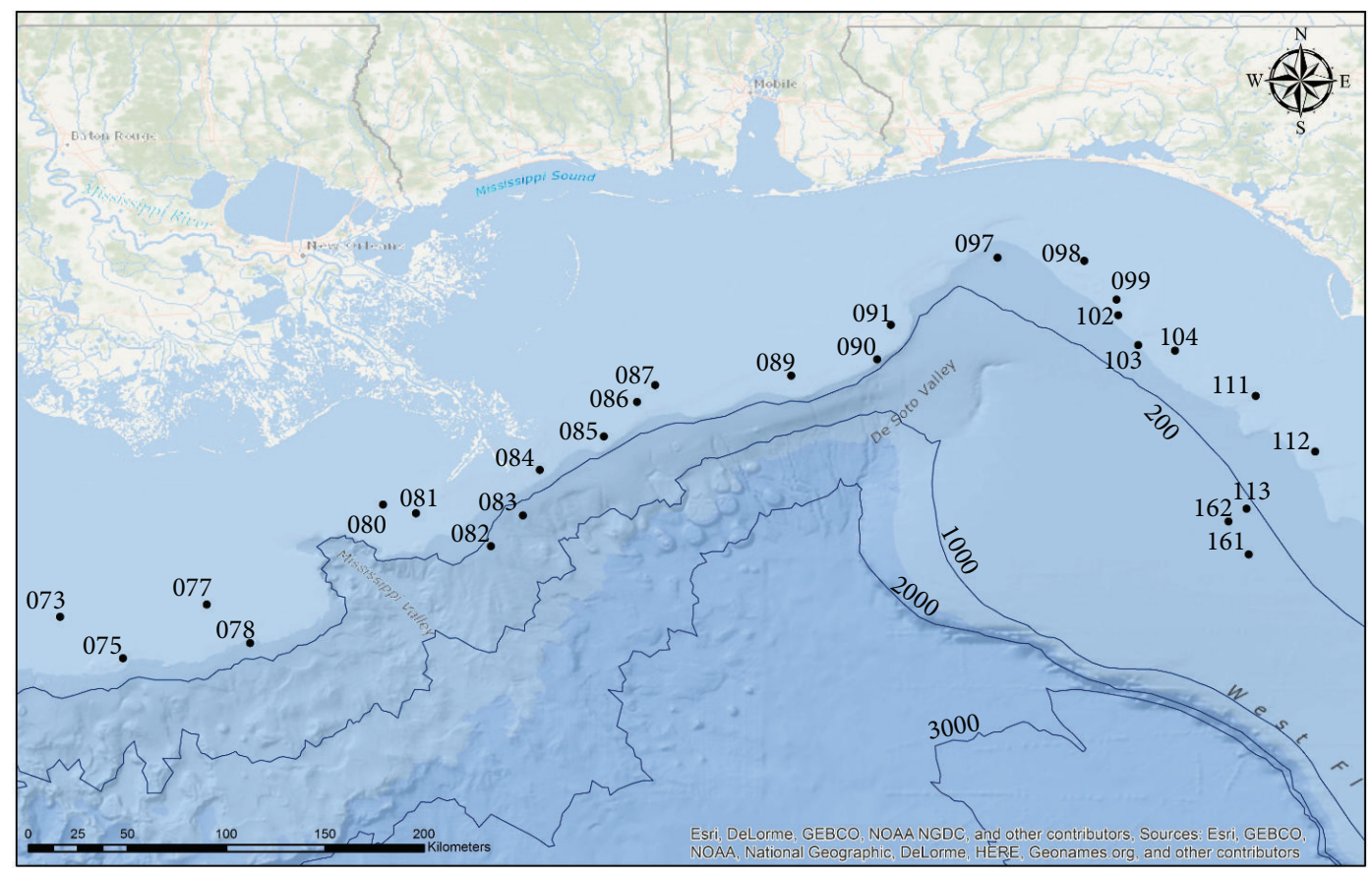

FIGURE 1: Sample locations in the northern GOM along the continental shelf and slope (contours in meters).

at room temperature, treated with $30 \%$ hydrogen peroxide, and heated to $45^{\circ} \mathrm{C}$ overnight to remove organic material. Dried material was separated using a Geotech Sand Shaker Mechanical Sieve (Geotech Environmental Equipment, Denver, $\mathrm{CO}$ ) into the following categories: granules $(>2 \mathrm{~mm})$, very coarse + coarse sand $(2 \mathrm{~mm}-500 \mu \mathrm{m})$, medium sand $(500 \mu \mathrm{m}-250 \mu \mathrm{m})$, fine sand $(250 \mu \mathrm{m}-125 \mu \mathrm{m})$, very fine sand $(125 \mu \mathrm{m}-63 \mu \mathrm{m})$, and silt + clay $(<63 \mu \mathrm{m})$.

2.6. Data Analysis. Negative longitudinal values were converted to positive values for statistical analysis (i.e., $87^{\circ} \mathrm{W}$ versus $-87^{\circ} \mathrm{W}$ ). Concentrations of trace metals and individual PAHs that were below detection limits were set at zero for graphing and statistical analysis. Nematode and copepod densities at each site were calculated as the mean number of individuals $/ 10 \mathrm{~cm}^{2}$. Metals were expressed in $\mathrm{mg} / \mathrm{kg}$ and PAHs in $\mu \mathrm{g} / \mathrm{kg}$, and granulometric characteristics and organic carbon were expressed as a percentage of the total sediment. Data were analyzed using the SPSS 12.0 Spearman's rank correlation.

\section{Results}

3.1. Sediment Metal Analysis. Analysis of metals focused on $\mathrm{Al}, \mathrm{Ba}, \mathrm{Ca}, \mathrm{Cr}, \mathrm{Cu}, \mathrm{Fe}, \mathrm{Ni}, \mathrm{Pb}, \mathrm{Sr}, \mathrm{V}$, and $\mathrm{Zn}$. This focus was due to the relationship of these metals to oil contamination and drilling and relevance to granulometry [16-20]. The data revealed two metal-related associations in the sediment, one to the west of sites $86 / 87$ (Figures 1-3; Table 1) and one to the east (Figure 4 ). These two sediment regions differed significantly in the concentrations of $\mathrm{Al}$ and $\mathrm{Ca}$, which had

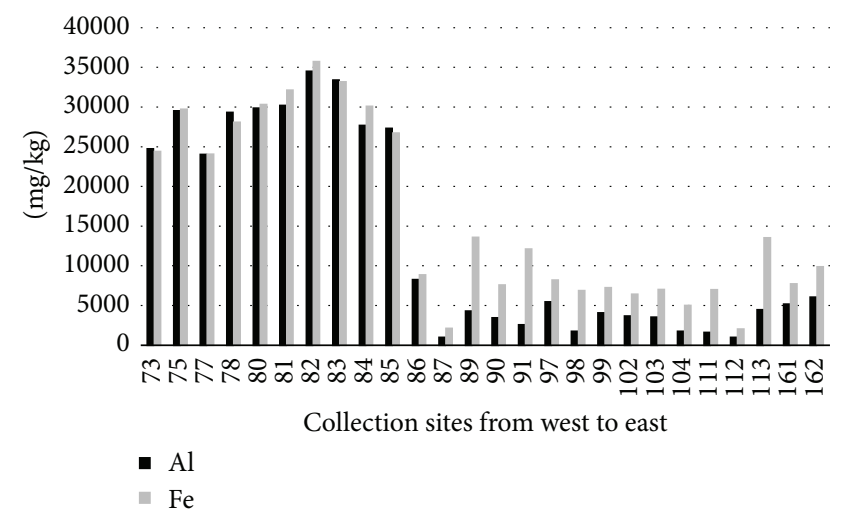

FIgURE 2: $\mathrm{Al}$ and Fe concentrations by site, from west to east along the GOM continental shelf.

markedly different correlations to the other metals (Figures 2, 4; Table 2).

Aluminum concentrations were highest in the western study areas (Figure 2). A sharp decline in Al concentration was found slightly east of the Mississippi River Delta, from $27,315 \mathrm{mg} / \mathrm{kg}$ at site 85 to $8,258 \mathrm{mg} / \mathrm{kg}$ at site 86 . This pattern was also seen with $\mathrm{Cr}, \mathrm{Cu}, \mathrm{Fe}, \mathrm{Ni}, \mathrm{Pb}, \mathrm{V}$, and $\mathrm{Zn}$, each of which correlated directly with $\mathrm{Al}$ and longitude (Figures 2, 3; Table 2). Barium also correlated significantly with $\mathrm{Al}$ and longitude and was present in much higher concentrations than most trace metals, reaching $1,124 \mathrm{mg} / \mathrm{kg}$ at site 78 .

Calcium had a significant negative trend when compared with $\mathrm{Al}, \mathrm{Ba}, \mathrm{Cr}, \mathrm{Cu}, \mathrm{Fe}, \mathrm{Ni}, \mathrm{Pb}, \mathrm{V}$, and $\mathrm{Zn}$ (Figure 4, Table 2). Concentrations of $\mathrm{Ca}$ were much higher in the eastern study sites, ranging from $4,120 \mathrm{mg} / \mathrm{kg}$ at site 81 to a peak of 
TABLE 2: Spearman's rank correlations $(r)$ between meiofauna density, granulometric and site characteristics, and trace metal, organic carbon, and PAH concentrations.

\begin{tabular}{|c|c|c|c|c|c|c|c|c|c|}
\hline & Nem & Cop & $\mathrm{N}: \mathrm{C}$ & $\mathrm{Al}$ & $\mathrm{Fe}$ & $\mathrm{Ca}$ & $\mathrm{Sr}$ & Long & Depth \\
\hline $\mathrm{Al}$ & $.541^{* *}$ & -.139 & $.439^{*}$ & 1.000 & $.935^{* * *}$ & $-.695^{* * *}$ & $-.757^{* * *}$ & $.733^{* * *}$ & $.429^{*}$ \\
\hline $\mathrm{Ba}$ & .368 & -.186 & .350 & $.895^{* * *}$ & $.846^{* * *}$ & $-.715^{* * *}$ & $-.782^{* * *}$ & $.848^{* * *}$ & .248 \\
\hline $\mathrm{Cr}$ & $.522^{* *}$ & -.167 & $.457^{*}$ & $.892^{* * *}$ & $.909^{* * *}$ & $-.657^{* * *}$ & $-.650^{* * *}$ & $.687^{* * *}$ & .347 \\
\hline $\mathrm{Cu}$ & $.503^{* *}$ & -.022 & .338 & $.949^{* * *}$ & $.916^{* * *}$ & $-.628^{* *}$ & $-.682^{* * *}$ & $.644^{* * *}$ & $.466^{*}$ \\
\hline $\mathrm{Fe}$ & $.406^{*}$ & -.119 & .366 & $.935^{* * *}$ & 1.000 & $-.656^{* * *}$ & $-.749^{* * *}$ & $.744^{* * *}$ & .302 \\
\hline $\mathrm{Ni}$ & $.496^{* *}$ & -.086 & .382 & $.961^{* * *}$ & $.911^{* * *}$ & $-.654^{* * *}$ & $-.704^{* * *}$ & $.652^{* * *}$ & $.492^{*}$ \\
\hline $\mathrm{Pb}$ & $.408^{*}$ & -.085 & .331 & $.869^{* * *}$ & $.868^{* * *}$ & $-.821^{* * *}$ & $-.813^{* * *}$ & $.793^{* * *}$ & .184 \\
\hline $\mathrm{V}$ & .370 & -.098 & .346 & $.933^{* * *}$ & $.965^{* * *}$ & $-.661^{* * *}$ & $-.721^{* * *}$ & $.774^{* * *}$ & .329 \\
\hline $\mathrm{Zn}$ & $.505^{* *}$ & -.146 & $.425^{*}$ & $.986^{* * *}$ & $.945^{* * *}$ & $-.669^{* * *}$ & $-.748^{* * *}$ & $.703^{* * *}$ & $.450^{*}$ \\
\hline $\mathrm{Ca}$ & $-.446^{*}$ & .204 & $-.432^{*}$ & $-.695^{* * *}$ & $-.656^{* * *}$ & 1.000 & $.932^{* * *}$ & $-.770^{* * *}$ & .134 \\
\hline $\mathrm{Sr}$ & -.367 & .085 & -.269 & $-.757^{* * *}$ & $-.749^{* * *}$ & $.932^{* * *}$ & 1.000 & $-.774^{* * *}$ & .092 \\
\hline Organic C & $.552^{* *}$ & -.237 & $.503^{*}$ & $.869^{* * *}$ & $.752^{* * *}$ & $-.696^{* * *}$ & $-.657^{* * *}$ & $.595^{* *}$ & $.416^{*}$ \\
\hline Silt + clay & $.409^{*}$ & -.060 & .298 & $.724^{* * *}$ & $.588^{* *}$ & $-.624^{* *}$ & $-.623^{* *}$ & $.535^{* *}$ & .238 \\
\hline Very coarse + coarse sand & -.024 & $.545^{* *}$ & -.385 & .073 & .193 & .108 & .027 & .013 & .060 \\
\hline ЕРA РP РАН & -.141 & .103 & -.331 & .210 & .053 & .045 & -.090 & .156 & .147 \\
\hline Total PAH & -.248 & .185 & $-.457^{*}$ & -.025 & -.124 & .220 & .102 & -.104 & .085 \\
\hline Long & .273 & -.150 & .274 & $.733^{* * *}$ & $.744^{* * *}$ & $-.770^{* * *}$ & $-.774^{* * *}$ & 1.000 & -.123 \\
\hline Depth & .251 & -.137 & .328 & $.429^{*}$ & .302 & .134 & .092 & -.123 & 1.000 \\
\hline
\end{tabular}

${ }^{*}$ Correlation is significant at 0.05 level.

${ }^{* *}$ Correlation is significant at 0.01 level.

${ }^{* * *}$ Correlation is significant at 0.001 level.

Nem: nematode density; Cop: copepod density; N : C: ratio of nematodes to copepods; Long: longitude.

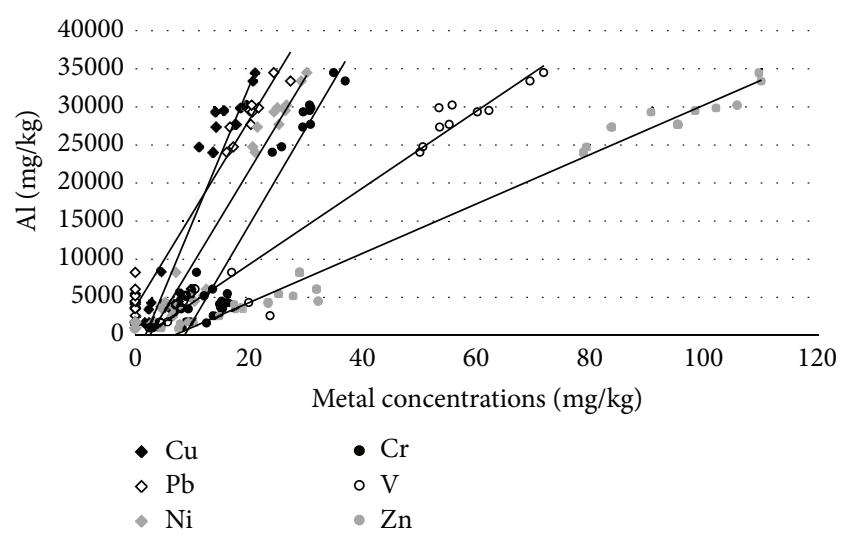

Figure 3: $\mathrm{Cu}, \mathrm{Pb}, \mathrm{Ni}, \mathrm{Cr}, \mathrm{V}$, and $\mathrm{Zn}$ concentrations graphed as a function of $\mathrm{Al}$ concentrations.

235,362 mg/kg at site 98 (Figure 4). Strontium concentrations were also much higher in the eastern study area, reaching $1,863 \mathrm{mg} / \mathrm{kg}$ at site 98 , located just northeast of the De Soto Valley. All sites west of sites $86 / 87$ contained strontium concentrations less than $300 \mathrm{mg} / \mathrm{kg}$.

3.2. Sediment PAH Analysis. Total PAH and EPA priority pollutant $\mathrm{PAH}$ concentrations were relatively low, ranging from 16 to $1,624 \mu \mathrm{g} / \mathrm{kg}$ (Table 3). Concentrations were not higher in Louisiana than in Florida, despite the proximity of the sites to the DHOS location $\left(28^{\circ} 44^{\prime} 12^{\prime \prime} \mathrm{N}\right.$, $\left.88^{\circ} 23^{\prime} 13.8^{\prime \prime} \mathrm{W}\right)$ and the extensive oil activities in coastal

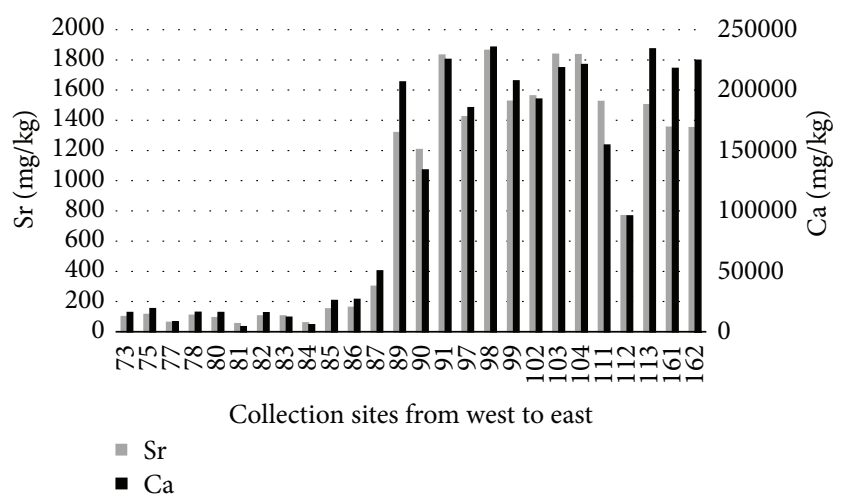

FIGURE 4: Sr and Ca concentrations by site, from west to east along the GOM continental shelf.

Louisiana [21]. The values were lowest in central study sites and generally increased in the east and the west (Figure 5). PAHs that were below detection limits at all locations included naphthalene, biphenyl, 2,6-dimethylnaphthalene, benzo(b)fluoranthene, benzo(k)fluoranthene, and perylene.

3.3. Sediment Granulometry Analysis. Granulometric analysis revealed differences in eastern versus western sites when comparing the silt + clay $(<63 \mu \mathrm{m})$ fraction with the very fine sand $(125 \mu \mathrm{m}-63 \mu \mathrm{m})$ fraction of the sediment (Figure 6$)$. The highest silt + clay (Figure 6) and organic carbon percentages (Table 3 ) were found in western sites and generally decreased in eastern sites, where very fine sandy sediments were more 
TABLE 3: Total PAH, total EPA priority pollutant PAH and organic carbon concentrations, and animal densities at each site.

\begin{tabular}{|c|c|c|c|c|c|}
\hline Site & Total PAH $(\mu \mathrm{g} / \mathrm{kg})$ & Total EPA PP PAH $(\mu \mathrm{g} / \mathrm{kg})$ & Organic carbon (\%) & Nematodes $/ 10 \mathrm{~cm}^{2}$ & Copepods $/ 10 \mathrm{~cm}^{2}$ \\
\hline 73 & 928 & 704 & 1.4 & 58 & 4 \\
\hline 75 & 1164 & 630 & 1.06 & 206 & 12 \\
\hline 77 & 1006 & 565 & 0.78 & 162 & 10 \\
\hline 78 & 815 & 327 & 1.01 & 52 & 2 \\
\hline 80 & 591 & 337 & 1.34 & 295 & 9 \\
\hline 81 & 234 & 177 & 1.33 & 245 & 2 \\
\hline 82 & 141 & 125 & 1.09 & 88 & 1 \\
\hline 83 & 16 & 16 & 1.4 & 376 & 5 \\
\hline 84 & 94 & 94 & 1.29 & 792 & 21 \\
\hline 85 & 144 & 144 & 1 & 132 & 3 \\
\hline 86 & 159 & 141 & 0.5 & 163 & 3 \\
\hline 87 & 231 & 196 & 0.33 & 37 & 3 \\
\hline 89 & 144 & 75 & 0.39 & 86 & 2 \\
\hline 90 & 109 & 68 & 0.43 & 70 & 1 \\
\hline 91 & 174 & 95 & 0.31 & 32 & 49 \\
\hline 97 & 339 & 183 & 1.06 & 193 & 5 \\
\hline 98 & 256 & 175 & 0.3 & 48 & 14 \\
\hline 99 & 278 & 123 & 0.77 & 340 & 8 \\
\hline 102 & 505 & 335 & 0.99 & 109 & 2 \\
\hline 103 & 619 & 325 & 0.83 & 74 & 1 \\
\hline 104 & 219 & 135 & 0.38 & 210 & 21 \\
\hline 111 & 351 & 110 & $\mathrm{x}$ & 70 & 2 \\
\hline 112 & 360 & 119 & 0.31 & 54 & 68 \\
\hline 113 & 1150 & 562 & 0.68 & 60 & 4 \\
\hline 161 & 886 & 395 & 0.79 & 104 & 11 \\
\hline 162 & 1624 & 818 & 0.83 & 66 & 13 \\
\hline
\end{tabular}

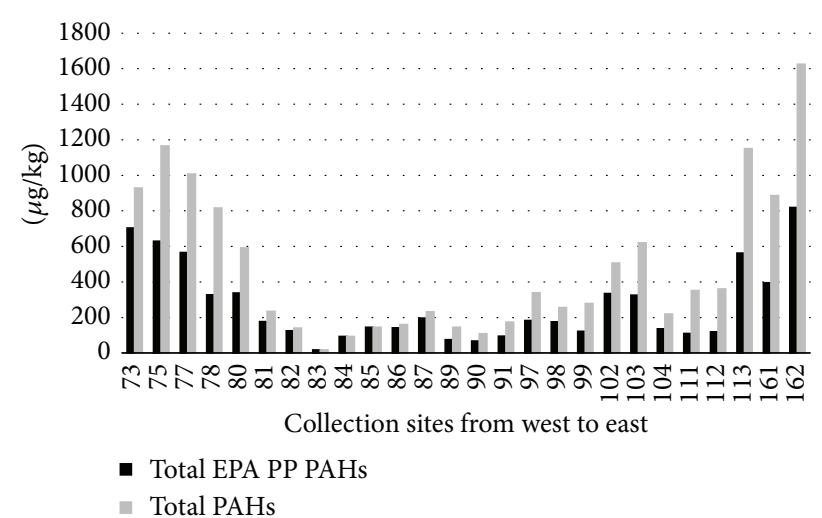

FIGURE 5: Total concentrations of the 16 EPA priority pollutant PAHs and total PAHs by site, from west to east along the GOM continental shelf.

prevalent. The very coarse + coarse sand percentage (relevant to copepod abundance) revealed no clear distribution pattern.

3.4. Meiofauna Density. Nematodes were generally more abundant in the western study sites, with the highest density of 792 nematodes $/ 10 \mathrm{~cm}^{2}$ at site 84 (Figure 7, Table 3) and

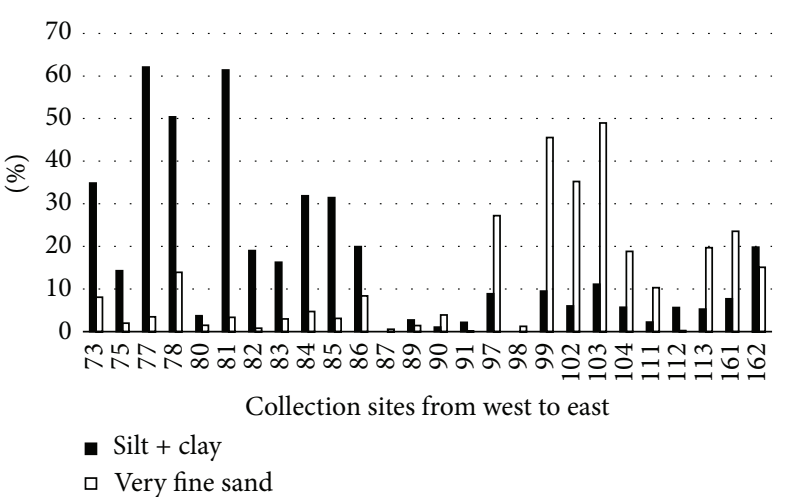

FIGURE 6: The silt + clay and very fine sand percentages of the sediment by site, from west to east along the GOM continental shelf.

a mean density of 159 nematodes $/ 10 \mathrm{~cm}^{2}$ across all sites. Conversely, the highest copepod (and copepodite) densities were found in eastern locations, with 68 copepods $/ 10 \mathrm{~cm}^{2}$ at site 112 (Figure 8, Table 3 ) and a mean density of 11 copepods $/ 10 \mathrm{~cm}^{2}$ across all sites. The ratio of nematodes to copepods $(\mathrm{N}: \mathrm{C})$, which has been used as an indicator in pollution studies $[22,23]$, was highest at site 81 where 


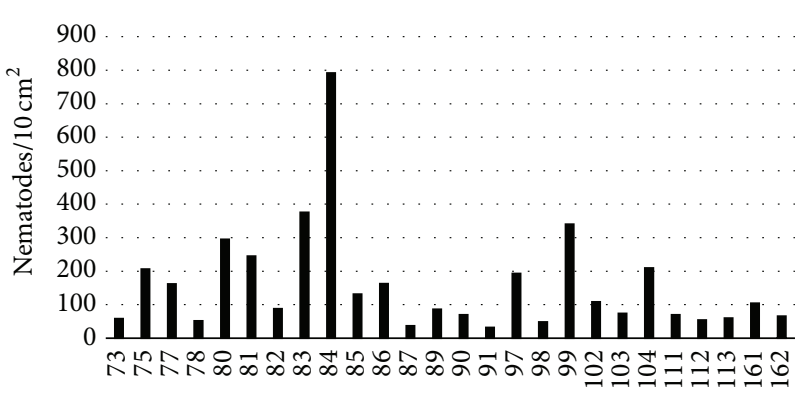

Collection sites from west to east

Figure 7: Nematode density by site, from west to east along the GOM continental shelf.

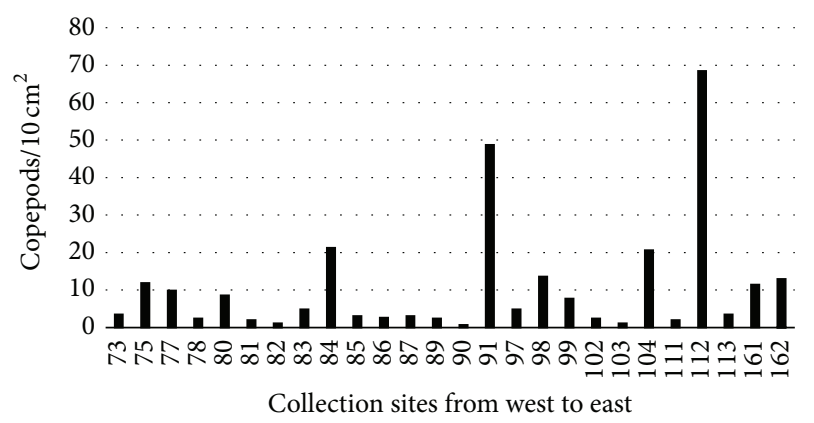

FIGURE 8: Copepod density by site, from west to east along the GOM continental shelf.

nematode density was over 100 times greater than copepod density (Table 3).

3.5. Statistical Correlations. Spearman's correlations support the trends observed in the raw data in that two distinct sediment zones exist along the continental shelf (Table 2). These two distinct areas can be observed via an analysis of metal type and concentration, granulometry, and meiofauna density.

3.5.1. Sediment Zones. The western area of the study revealed strong positive correlations between $\mathrm{Al}$ and $\mathrm{Ba}, \mathrm{Cr}, \mathrm{Cu}, \mathrm{Fe}$, $\mathrm{Ni}, \mathrm{Pb}, \mathrm{V}$, and $\mathrm{Zn}$, all of which correlated positively with longitude (Figures 2-3, Table 2). Organic carbon (Table 3) and silt + clay percentages (Figure 6) also correlated with longitude and were found in higher percentages in western sites (Table 2). In contrast, sediments from the eastern study area consisted of high concentrations of $\mathrm{Sr}$ and $\mathrm{Ca}$ (both negatively correlated with longitude) (Figure 4, Table 2) and very fine sand (Figure 6).

3.5.2. Meiofauna. Nematode density positively correlated with concentrations of $\mathrm{Al}, \mathrm{Cr}, \mathrm{Cu}, \mathrm{Fe}, \mathrm{Ni}, \mathrm{Pb}$, and $\mathrm{Zn}$ and silt + clay and organic carbon percentages (Table 2). Nematode density and $\mathrm{N}: \mathrm{C}$ were both negatively correlated with $\mathrm{Ca}$, while $\mathrm{N}$ : C negatively correlated with total PAHs (Table 2). Copepod density correlated positively with very coarse + coarse sandy sediments (Table 2).

\section{Discussion}

This study documents the sharp contrast in sediment characteristics that exists on the northern GOM continental shelf. The low concentrations of $\mathrm{Al}$ east of the Mississippi River Delta and the sharp increase in concentrations near site 86 are likely attributable to the outflow of the Mississippi River, which is rich with terrestrial-derived $\mathrm{Al}$ from the weathering of continental rocks [24]. Weathered Al complexes with silicate material and aggregates other trace metals to form aluminosilicate clay minerals [24, 25].

Since trace metals are naturally found in aluminosilicate minerals, $\mathrm{Al}$ is often used to normalize their concentrations $[20,25,26]$. In the current study, the correlation of $\mathrm{Cr}, \mathrm{Cu}$, $\mathrm{Fe}, \mathrm{Ni}, \mathrm{Pb}, \mathrm{V}$, and $\mathrm{Zn}$ with $\mathrm{Al}$ (and longitude) suggests that these metal variations are naturally occurring, likely bound with silicate, clayey material derived from the outflow of the Mississippi River and not from anthropogenic input [19, 20, 24]. McGowen et al. [19] found that these metals (with the exception of $\mathrm{Zn}$, which was not measured) were highly present in fluvial sediments and several showed an affinity for fine sediments with high organic carbon content, as found in our study.

Similar to $\mathrm{Al}$, Fe concentrations may be used to normalize trace metals and reveal those concentrations that are attributable to river outflow [20, 27]. Iron concentrations in this study correlated strongly with $\mathrm{Al}$ and showed a similar relationship to that of $\mathrm{Al}$ with the remaining metals. Barium also correlated with $\mathrm{Al}$ in this study, though it is likely elevated due to the high concentration of $\mathrm{Ba}$ in drilling muds and the high frequency of drilling operations in the western part of the study area, where Mississippi Riverderived aluminosilicate minerals are prevalent $[20,28]$. Thus, although elevated $\mathrm{Ba}$ correlated with elevated $\mathrm{Al}$ in the west, this correlation may be a reflection of drilling operations and not entirely attributable to Mississippi River outflow.

Mississippi River outflow in the GOM is primarily influenced by a strong westward current along the Louisiana/Texas (LATEX) shelf as well as a northeastward current flowing alongside the Mississippi/Alabama/Florida (MAFLA) shelf [29]. The westward LATEX current explains the significant increase in trace metal concentrations west of the Mississippi River Delta. Outflow from the Mississippi River Delta is dominated by the westward current, carrying with it Mississippi-derived aluminosilicate compounds, resulting in higher metal concentrations west of the river delta. Similarly, Holmes [30] found an increase in trace metals ( $\mathrm{Ba}, \mathrm{Cr}, \mathrm{Cu}, \mathrm{Ni}, \mathrm{Pb}$, and $\mathrm{V}$ ) in the northwestern GOM shelf, when compared with the southeastern GOM shelf. In addition, Wade et al. [20] found that Be, Co, Cr, Fe, Si, Tl, $\mathrm{V}, \mathrm{Zn}, \mathrm{K}$, and $\mathrm{Mg}$ correlated with $\mathrm{Al}$ and were derived from Mississippi River lithogenic silicate material.

Strontium and $\mathrm{Ca}$ are chemically similar, showing a high affinity for carbonate, rather than fine silicate material. Therefore, the negative correlation of $\mathrm{Sr}$ and $\mathrm{Ca}$ with $\mathrm{Al}$ and other trace metals and the sharp increase in $\mathrm{Sr}$ and Ca concentrations east of site 86 are likely due to this relationship. Sediments in the eastern GOM have higher carbonate levels primarily derived from calcium carbonate 
shells of planktonic foraminifera and coccolithophores [3032]. Morse et al. [31] reported that the majority of carbonate minerals in marine sedimentary environments are biogenic in origin, precipitated by living organisms. Though $\mathrm{Sr}$ and $\mathrm{Ca}$ are largely derived from river output [33], these metals are not influenced by organic carbon, silt + clay, or fine silicate material, and therefore settling and distribution of these metals in marine sediments are likely attributable to the availability of carbonate material [19]. This explains the elevated concentrations of $\mathrm{Sr}$ and $\mathrm{Ca}$ observed in eastern areas of this study, where carbonate is more prevalent. The natural groupings of metals observed in the present study are supported by the findings of many previous studies $[19,20$, $27,30]$.

The mean concentrations of $\mathrm{Ba}, \mathrm{Cr}, \mathrm{Cu}, \mathrm{Ni}, \mathrm{Pb}, \mathrm{V}$, and $\mathrm{Zn}$ in the current study were lower than those reported from the northern GOM slope by Wade et al. [20]. However, our values are grouped into high and low concentrations based on location, so mean values are of limited use. The higher concentrations for these trace metals, found in the western sites, are more comparable to the aforementioned report [20]. Concentrations of $\mathrm{Cr}, \mathrm{Cu}, \mathrm{Pb}$, and $\mathrm{Zn}$ were below the NOAA aquatic-life benchmark lower screening value for sediment contamination. Nickel concentrations at most western sites exceeded the aquatic-life benchmark lower screening value $(20.9 \mathrm{mg} / \mathrm{kg})$, but all concentrations were below the upper screening value $(51.6 \mathrm{mg} / \mathrm{kg})$ for sediment contamination predicted to have effects on aquatic organisms [34]. Vanadium concentrations in several western sites exceeded the EPA chronic exposure benchmark ( $57 \mathrm{mg} / \mathrm{kg})$, while all eastern sites were below this benchmark [35]. Wade et al. (2008) found a mean Ni concentration of $38 \mathrm{mg} / \mathrm{kg}$ and a mean $\mathrm{V}$ concentration of $100 \mathrm{mg} / \mathrm{kg}$ for the northern GOM shelf and slope [20]. Various other studies also reported higher yet comparable values for $\mathrm{Ni}$ and $\mathrm{V}$ than those reported in the current study [36-39]. The strong correlation of $\mathrm{Ni}$ and $\mathrm{V}$ with $\mathrm{Al}$ in this study suggests that the concentrations of these metals are mostly attributable to natural aluminosilicate minerals [20,40]. These concentrations may also be enhanced in Louisiana due to drilling activity and adsorption to the fine sediment in the area.

Barium concentrations in this study ranged from 5 to $1,124 \mathrm{mg} / \mathrm{kg}$; however, many sites in the GOM contain $\mathrm{Ba}$ concentrations in excess of tens of thousands of $\mathrm{mg} / \mathrm{kg}$ $[16,41]$. The values found in this study are similar to that of a previous study in the Southern California Bight, where $\mathrm{Ba}$ concentrations ranged from 43 to $1,899 \mathrm{mg} / \mathrm{kg}$ in benthic sediments and from 145 to $1,259 \mathrm{mg} / \mathrm{kg}$ in intertidal sediments $[42,43]$. Higher concentrations are usually found near drilling platforms and other drilling operations [16, 43]. A study in the Santa Maria Basin off the west coast of California yielded Ba concentrations of $923 \mathrm{mg} / \mathrm{kg}$ within a $500 \mathrm{~m}$ distance from a drilling platform and $869 \mathrm{mg} / \mathrm{kg}$ at $1000 \mathrm{~m}$ from the platform $[43,44]$. The sites with the highest concentrations of $\mathrm{Ba}$ in this study were within the general proximity of the most Ba-enriched sites reported by the U.S. Department of the Interior's Minerals Management Service, in an area of intense petroleum exploration [41].
Strontium concentrations in this study ranged from 53 to $1,863 \mathrm{mg} / \mathrm{kg}$ and were much higher in the eastern shelf areas. Calcium was also much higher in eastern shelf areas, ranging from 4,120 to $235,362 \mathrm{mg} / \mathrm{kg}$. Similarly, Holmes [30] reported mean Sr concentrations of $198 \mathrm{mg} / \mathrm{kg}$ and $1,060 \mathrm{mg} / \mathrm{kg}$ for the northwestern and northeastern GOM shelf/slopes and mean Ca concentrations of $15,800 \mathrm{mg} / \mathrm{kg}$ to $286,000 \mathrm{mg} / \mathrm{kg}$ in western Gulf versus Florida shelf sediments.

Total PAHs were negatively correlated with $\mathrm{N}$ : C; however, all PAHs in this study were well below the benchmark value (PAH lower screening value: $4,022 \mu \mathrm{g} / \mathrm{kg}$ ) for sediment contamination expected to cause biological effects [34]. A previous study also determined that PAHs in coastal Louisiana and Mississippi sediments collected in 2012 were well below the level expected to cause effects [45]. Therefore, the negative correlation of $\mathrm{N}$ : C with PAHs was likely due to a difference in sediment grain size preference rather than a direct effect of PAHs. The low PAH concentrations detected in this study coincide with low (0.3-1.4\%) organic carbon levels. Natter et al. [46] found that oiled sediments from coastal marshes in Alabama, Louisiana, and Mississippi contained significantly higher levels of organic carbon (10-28\%) than unpolluted sediments $(<3 \%)$.

Meiofauna correlations with sediment characteristics reported herein are consistent with previous studies. Those studies have reported increased copepod grazing in sediments with larger grain sizes [47], while nematodes thrive in siltier sediments that are rich in organic matter $[6,48]$. In the current study, the highest copepod densities were observed in eastern study sites, where silt + clay percentage greatly decreased and the sandier sediments became more prevalent. Increased nematode density was observed in western study sites, where silt + clay was dominant and high organic carbon and trace metal concentrations were found. The relationship between silt + clay percentage, organic carbon, and $\mathrm{Al}$ is supported by earlier work that demonstrated a direct relationship between these variables in coastal sediments [27]. Their research suggested that $\mathrm{Al}$ could be used as a surrogate for grain size analysis because of these strong correlations. Nematode densities now appear to fit within that relationship with silt + clay percentage, organic carbon, and Al. No such clear relationship between copepods, trace metals, and granulometry was found in the current study, though copepod density did correlate with the very coarse + coarse sand type (which revealed no clear distribution pattern). Overall, nematodes and copepods appear to be influenced by sediment grain size and organic carbon rather than sediment pollutants.

Raw data from a three-year (2007-2009) meiofauna study by Landers et al. [49] was reexamined to focus only on those locations within the same longitudinal range as in the current study. This examination revealed a mean of 85 nematodes $/ 10 \mathrm{~cm}^{2}$ and 6 copepods $/ 10 \mathrm{~cm}^{2}$, while the current study reports 159 nematodes $/ 10 \mathrm{~cm}^{2}$ and 11 copepods $/ 10 \mathrm{~cm}^{2}$. The nematode densities were particularly higher in sites 73-86 compared to similar sites from 2007 to 2009 (233 nematodes $/ 10 \mathrm{~cm}^{2}$ in 2012 versus 87 nematodes $/ 10 \mathrm{~cm}^{2}$ in 2007-2009). Recent collections using a multicorer from these locations may help to explain this variation. 
Findings from the current study were comparable to those of previous meiofauna studies on continental shelf and slope systems in various parts of the world. Netto et al. [50] found mean densities similar to the current study, with 129 nematodes $/ 10 \mathrm{~cm}^{2}$ and 16 copepods $/ 10 \mathrm{~cm}^{2}$ on the continental slope near the coast of southeastern Brazil, at a depth of $215( \pm 14) \mathrm{m}$. In a Kenyan continental slope study in the western Indian Ocean, nematode densities ranged from 276 to 944 individuals $/ 10 \mathrm{~cm}^{2}$, though they reported that these numbers were higher due to conspicuously higher densities observed at $20 \mathrm{~m}$ depths (significantly shallower than any samples from the current study) [51]. At sites from the northeast Atlantic shelf break, a mean nematode density of 250 individuals $/ 10 \mathrm{~cm}^{2}$ was observed [52]. In sediments from the western continental shelf of India in the Arabian Sea, nematode densities ranged from about 100 to 300 individuals $/ 10 \mathrm{~cm}^{2}$, with the lower densities observed in sandy sediments and the highest in silt + clay sediments. Copepods showed a reverse trend as they were more prevalent in sandy sediments [53]. This link between meiofauna and sediment grain size supports the current study's findings. Nematodes and copepods of the GOM continental shelf show no indication of changes in abundance attributable to sediment pollutants, which were found at relatively low levels when compared with benchmarks and findings from previous studies, and therefore do not appear to have been affected by anthropogenic disturbance.

\section{Conclusions}

This study documents the two distinct sediment zones that exist along the continental shelf of the northern Gulf of Mexico. The shelf sediments in the western study area were heavily influenced by runoff from the Mississippi River, while sediments in the eastern study area were influenced by naturally occurring carbonate material. Meiofauna densities appeared to be most influenced by sediment type and not trace metals or PAHs.

\section{Conflict of Interests}

The authors declare that there is no conflict of interests regarding the publication of this paper.

\section{Acknowledgments}

This research was made possible by a grant from BP/The Gulf of Mexico Research Initiative. The authors thank NOAA, the scientists, and staff at the National Marine Fisheries Service Pascagoula Laboratory, Syam Dodla and Jeff Corkern (LSU), and student researchers at Troy University and Jacksonville State University for contributing to this study. Additionally, the authors thank Terry Wade (Texas A\&M University) for his helpful comments on this paper. Data from five collection sites in this study have been previously reported [9].

\section{References}

[1] P. A. Montagna, J. G. Baguley, C. Cooksey et al., "Deep-sea benthic footprint of the Deepwater Horizon blowout," PLoS ONE, vol. 8, no. 8, Article ID e70540, 2013.

[2] E. L. Floyd, C. T. Lungu, and J. M. Gohlke, "An evaluation of nearshore sediment data after the Deepwater Horizon blowout," Journal of Environmental Science and Engineering, vol. 1, no. 3, pp. 341-350, 2012.

[3] J. S. Hayworth, T. P. Clement, and J. F. Valentine, "Deepwater Horizon oil spill impacts on Alabama beaches," Hydrology and Earth System Sciences, vol. 15, pp. 3639-3649, 2011.

[4] NOAA, "Incident Report: Jack up rig Hercules 265," U.S. Department of Commerce, Office of Response and Restoration, 2013, http://incidentnews.noaa.gov/incident/8638.

[5] NOAA, Incident Report: Kirby Barge Oil Spill, Houston/Texas City Ship Channel, Port Bolivar, Texas, U.S. Department of Commerce, Office of Response and Restoration, 2014, http://response.restoration.noaa/oil-spills/kirby-barge-oil-spillhoustontexas-city-ship-channel-port-bolivar.

[6] J. Sharma, J. G. Baguley, P. A. Montagna, and G. T. Rowe, "Assessment of longitudinal gradients in nematode communities in the deep northern Gulf of Mexico and concordance with benthic taxa," International Journal of Oceanography, vol. 2012, Article ID 903018, 15 pages, 2012.

[7] C.-L. Wei, G. T. Rowe, G. Fain Hubbard et al., "Bathymetric zonation of deep-sea macrofauna in relation to export of surface phytoplankton production," Marine Ecology Progress Series, vol. 399, pp. 1-14, 2010.

[8] O. Giere, Meiobenthology: The Microscopic Motile Fauna of Aquatic Sediments, Springer, Berlin, Germany, 2nd edition, 2009.

[9] S. C. Landers, A. C. Nichols, N. K. Barron et al., "Nematode and copepod diversity (2012) from Louisiana near the Deepwater Horizon oil spill," Proceedings of the Biological Society of Washington, vol. 127, no. 1, pp. 47-57, 2014.

[10] R. Burgess, "An improved protocol for separating meiofauna from sediments using colloidal silica sols," Marine Ecology Progress Series, vol. 214, pp. 161-165, 2001.

[11] J. G. Baguley, P. A. Montagna, L. J. Hyde, R. D. Kalke, and G. T. Rowe, "Metazoan meiofauna abundance in relation to environmental variables in the northern Gulf of Mexico deep sea," Deep-Sea Research Part I: Oceanographic Research Papers, vol. 53, no. 8, pp. 1344-1362, 2006.

[12] R. P. Higgins and H. Thiel, Introduction to the Study of Meiofauna, Smithsonian Institution Press, Washington, DC, USA, 1988.

[13] USEPA, Method 3540C. Soxhlet Extraction: Test Methods for Evaluating Solid Waste, Physical/Chemical Methods, EPA/SW846, U.S. Environmental Protection Agency, Washington, DC, USA, 3rd edition, 1996.

[14] USEPA, Method 200.7. Trace Elements in Water, Solids, and Biosolids by Inductively Coupled Plasma-Atomic Emission Spectrometry, EPA-821-R-01-010, U.S. Environmental Protection Agency, Washington, DC, USA, 5th edition, 2001.

[15] USEPA, "Method 9060. Total organic carbon (TOC) in soil," Tech. Rep. EPA/SW-846, U.S. Environmental Protection Agency, Washington, DC, USA, 1999.

[16] P. N. Boothe and B. J. Presley, "Trends in sediment trace element concentration around six petroleum drilling platforms in the northwestern Gulf of Mexico," in Drilling Wastes, F. R. 
Engelhardt, J. P. Ray, and A. H. Gillam, Eds., Elsevier Applied Science, London, UK, 1989.

[17] M. Y. Khuhawar, M. A. Mirza, and T. M. Jahangir, "Determination of metal ions in crude oils," in Crude Oil EmulsionsComposition Stability and Characterization, M. El-Sayed, Ed., pp. 121-144, InTech, Rijeka, Croatia, 2012.

[18] Z. Liu, J. Liu, Q. Zhu, and W. Wu, "The weathering of oil after the Deepwater Horizon oil spill: insights from the chemical composition of the oil from the sea surface, salt marshes and sediments," Environmental Research Letters, vol. 7, no. 3, Article ID 035302, 2012.

[19] J. H. McGowen, J. R. Byrne, and B. H. Wilkinson, Geochemistry of Bottom Sediments-Matagorda Bay System, Texas, University of Texas at Austin, Bureau of Economic Geology, Austin, Tex, USA, 1979.

[20] T. L. Wade, Y. Soliman, S. T. Sweet, G. A. Wolff, and B. J. Presley, "Trace elements and polycyclic aromatic hydrocarbons (PAHs) concentrations in deep Gulf of Mexico sediments," Deep-Sea Research Part II: Topical Studies in Oceanography, vol. 55, no. 24-26, pp. 2585-2593, 2008.

[21] NOAA, Incident Report: Deepwater Horizon, U.S. Department of Commerce, Office of Response and Restoration, Washington, DC, USA, 2010, http://incidentnews.noaa.gov/incident/8220.

[22] D. Raffaelli, "The behaviour of the nematode/copepod ratio in organic pollution studies," Marine Environmental Research, vol. 23, no. 2, pp. 135-152, 1987.

[23] G. M. Shiells and K. J. Anderson, "Pollution monitoring using the nematode/copepod ratio," Marine Pollution Bulletin, vol. 16, no. 2, pp. 62-68, 1985.

[24] R. A. Feely, W. M. Sackett, and J. E. Harris, "Distribution of particulate aluminum in the Gulf of Mexico," Journal of Geophysical Research, vol. 76, no. 24, pp. 5893-5902, 1971.

[25] S. J. Schropp and H. L. Windom, Eds., A Guide to the Interpretation of Metal Concentrations in Estuarine Sediments, Florida Department of Environmental Regulation, Coastal Zone Management Section, Tallahassee, Fla, USA, 1988.

[26] J. H. Trefry, S. Metz, R. P. Trocine, and T. A. Nelsen, "A decline in lead transport by the Mississippi River," Science, vol. 230, no. 4724, pp. 439-441, 1985.

[27] J. K. Summers, T. L. Wade, V. D. Engle, and Z. A. Malaeb, "Normalization of metal concentrations in estuarine sediments from the Gulf of Mexico," Estuaries, vol. 19, no. 3, pp. 581-594, 1996.

[28] J. M. Neff, "Estimation of bioavailability of metals from drilling mud barite," Integrated Environmental Assessment and Management, vol. 4, no. 2, pp. 184-193, 2008.

[29] V. H. Kourafalou and Y. S. Androulidakis, "Influence of Mississippi River induced circulation on the Deepwater Horizon oil spill transport," Journal of Geophysical Research C: Oceans, vol. 118, no. 8, pp. 3823-3842, 2013.

[30] C. Holmes, Distribution of Selected Elements in Surficial Marine Sediments of the Northern Gulf of Mexico Continental Shelf and Slope, U.S. Government Printing Office, Washington, DC, USA, 1973.

[31] J. W. Morse, R. S. Arvidson, and A. Lüttge, "Calcium carbonate formation and dissolution," Chemical Reviews, vol. 107, no. 2, pp. 342-381, 2007.

[32] W. W. Hay, "Carbonate fluxes and calcareous nannoplankton," in Coccolithophores-From Molecular Processes to Global Impact, H. R. Thierstein and J. R. Young, Eds., pp. 509-528, Springer, Berlin, Germany, 2004.
[33] D. W. Graham, M. L. Bender, D. F. Williams, and L. D. Keigwin Jr., "Strontium-calcium ratios in Cenozoic planktonic foraminifera," Geochimica et Cosmochimica Acta, vol. 46, no. 7, pp. 1281-1292, 1982.

[34] L. H. Nowell, A. S. Ludtke, D. K. Mueller, and J. C. Scott, "Organic contaminants, trace and major elements, and nutrients in water and sediment sampled in response to the Deepwater Horizon oil spill," U.S. Geological Survey Open File Report 2012-5228, U.S. Department of the Interior, Washington, DC, USA, 2013.

[35] USEPA, "Sediment benchmarks for aquatic life," in EPA Response to BP Spill in the Gulf of Mexico, U.S. Environmental Protection Agency, Washington, DC, USA, 2013, http://www.epa.gov/bpspill/sediment-benchmarks.html.

[36] J. V. MacÍas-Zamora, J. A. Villaescusa-Celaya, A. MuñozBarbosa, and G. Gold-Bouchot, "Trace metals in sediment cores from the Campeche shelf, Gulf of Mexico," Environmental Pollution, vol. 104, no. 1, pp. 69-77, 1999.

[37] A. R. Mostafa, A. O. Barakat, Y. Qian, T. L. Wade, and D. Yuan, "An overview of metal pollution in the Western Harbour of Alexandria, Egypt," Soil and Sediment Contamination, vol. 13, no. 3, pp. 299-311, 2004.

[38] W. Salomons and W. G. Mook, "Trace metal concentrations in estuarine sediments: mobilization, mixing or precipitation," Netherlands Journal of Sea Research, vol. 11, no. 2, pp. 119-129, 1977.

[39] F. G. Vazquez, V. K. Sharma, and L. Perez-Cruz, "Concentrations of elements and metals in sediments of the southeastern Gulf of Mexico," Environmental Geology, vol. 42, no. 1, pp. 41-46, 2002.

[40] H. L. Windom, S. J. Schropp, F. D. Calder et al., "Natural trace metal concentrations in estuarine and coastal marine sediments of the southeastern United States," Environmental Science and Technology, vol. 23, no. 3, pp. 314-320, 1989.

[41] G. T. Rowe and M. C. Kennicutt II, "Deepwater program: Northern Gulf of Mexico continental slope habitat and benthic ecology," Year 2: Interim Report OCS Study MMS 2002-063, U.S. Department of the Interior, Minerals Management Service, New Orleans, La, USA, 2002.

[42] T. J. Chow, J. L. Earl, J. H. Reed, N. Hansen, and V. Orphan, "Barium content of marine sediments near drilling sites: a potential pollutant indicator," Marine Pollution Bulletin, vol. 9, no. 4, pp. 97-99, 1978.

[43] D. Moffett, C. Smith-Simon, and S. Yee-Wan, Toxicological Profile for Barium and Barium Compounds, Agency for Toxic Substances and Disease Registry, US Department of Health and Human Services, 2007.

[44] C. Phillips, J. Evans, W. Hom, and J. Clayton, "Long-term changes in sediment barium inventories associated with drilling-related discharges in the Santa Maria Basin, California, USA," Environmental Toxicology and Chemistry, vol. 17, no. 9, pp. 1653-1661, 1998.

[45] Z. Wang, Z. Liu, K. Xu et al., "Concentrations and sources of polycyclic aromatic hydrocarbons in surface coastal sediments of the northern Gulf of Mexico," Geochemical Transactions, vol. 15, no. 1, article 2, 2014.

[46] M. Natter, J. Keevan, Y. Wang et al., "Level and degradation of deepwater horizon spilled oil in coastal marsh sediments and pore-water," Environmental Science and Technology, vol. 46, no. 11, pp. 5744-5755, 2012.

[47] M. de Troch, L. Houthoofd, V. Chepurnov, and A. Vanreusel, "Does sediment grain size affect diatom grazing by harpacticoid 
copepods?" Marine Environmental Research, vol. 61, no. 3, pp. 265-277, 2006.

[48] J. W. Fleeger and G. T. Chandler, "Meiofauna responses to an experimental oil spill in a Louisiana salt marsh," Marine Ecology Progress Series, vol. 11, pp. 257-264, 1983.

[49] S. C. Landers, F. A. Romano III, P. M. Stewart, and S. Ramroop, "A multi-year survey of meiofaunal abundance from the northern Gulf of Mexico continental shelf and slope," Gulf of Mexico Science, vol. 1, no. 2, pp. 20-29, 2012.

[50] S. A. Netto, F. Gallucci, and G. F. C. Fonseca, "Meiofauna communities of continental slope and deep-sea sites off SE Brazil," Deep-Sea Research Part I: Oceanographic Research Papers, vol. 52, no. 5, pp. 845-859, 2005.

[51] A. W. Muthumbi, A. Vanreusel, G. Duineveld, K. Soetaert, and M. Vincx, "Nematode community structure along the continental slope off the Kenyan coast, Western Indian Ocean," International Review of Hydrobiology, vol. 89, no. 2, pp. 188-205, 2004.

[52] K. Soetaert and C. Heip, "Nematode assemblages of deep-sea and shelf break sites in the North Atlantic and Mediterranean Sea," Marine Ecology Progress Series, vol. 125, no. 1-3, pp. 171183, 1995.

[53] S. Sajan, T. V. Joydas, and R. Damodaran, "Meiofauna of the western continental shelf of India, Arabian Sea," Estuarine, Coastal and Shelf Science, vol. 86, no. 4, pp. 665-674, 2010. 

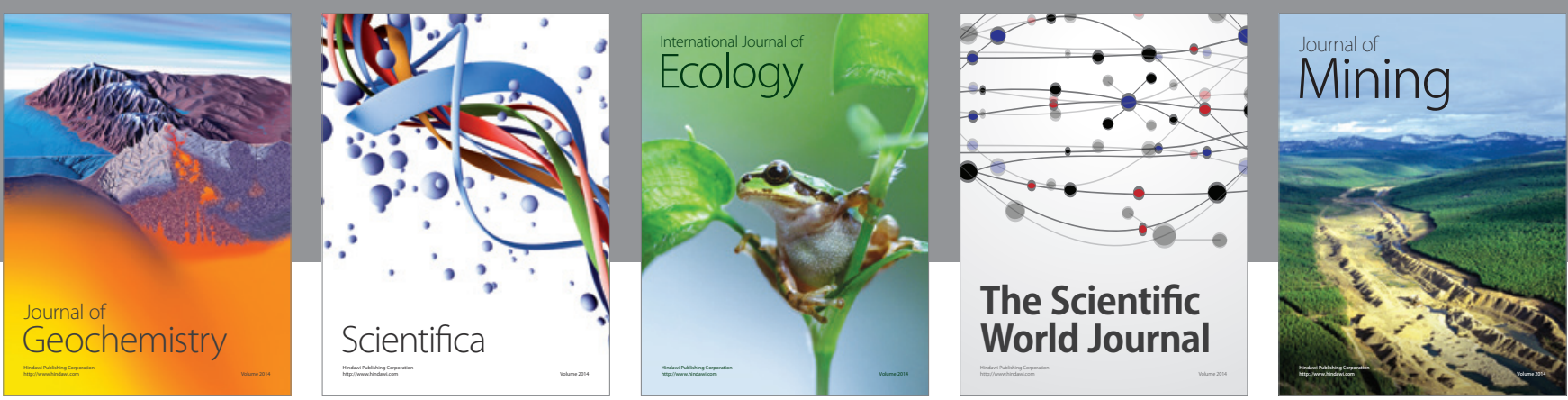

The Scientific World Journal
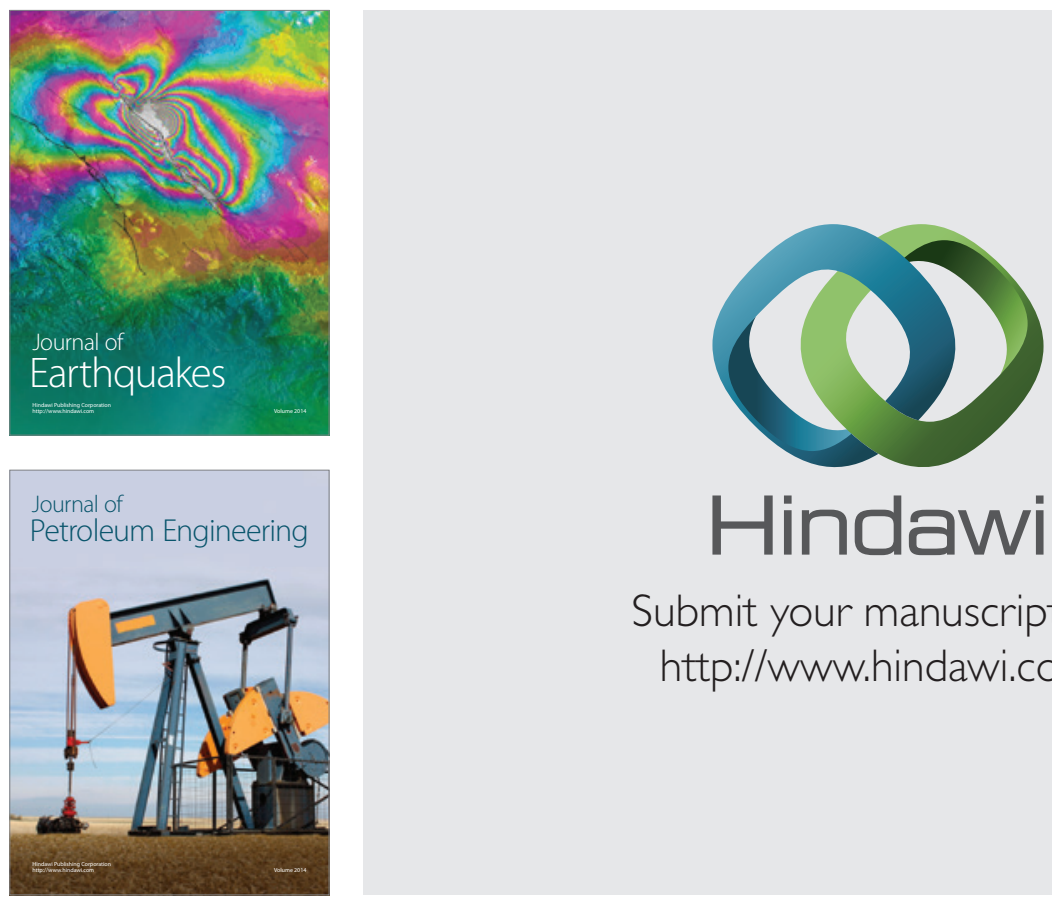

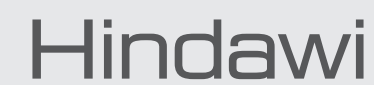

Submit your manuscripts at

http://www.hindawi.com
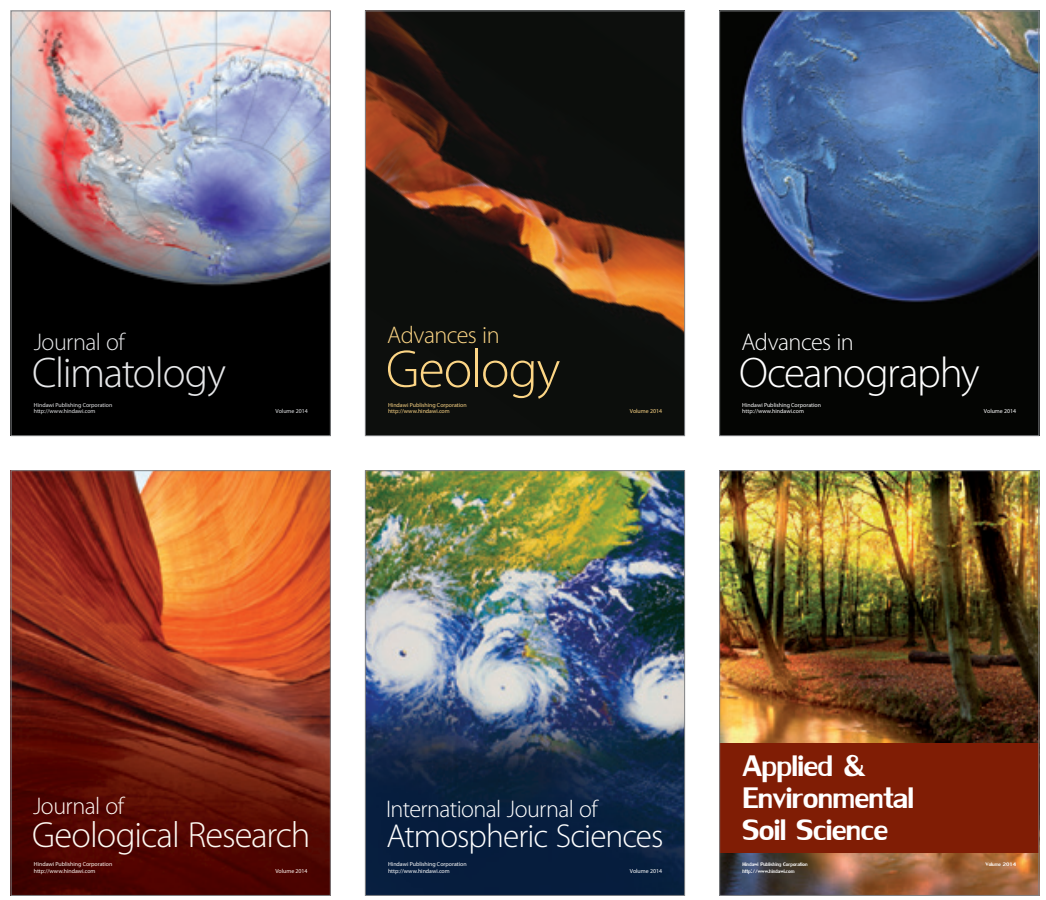
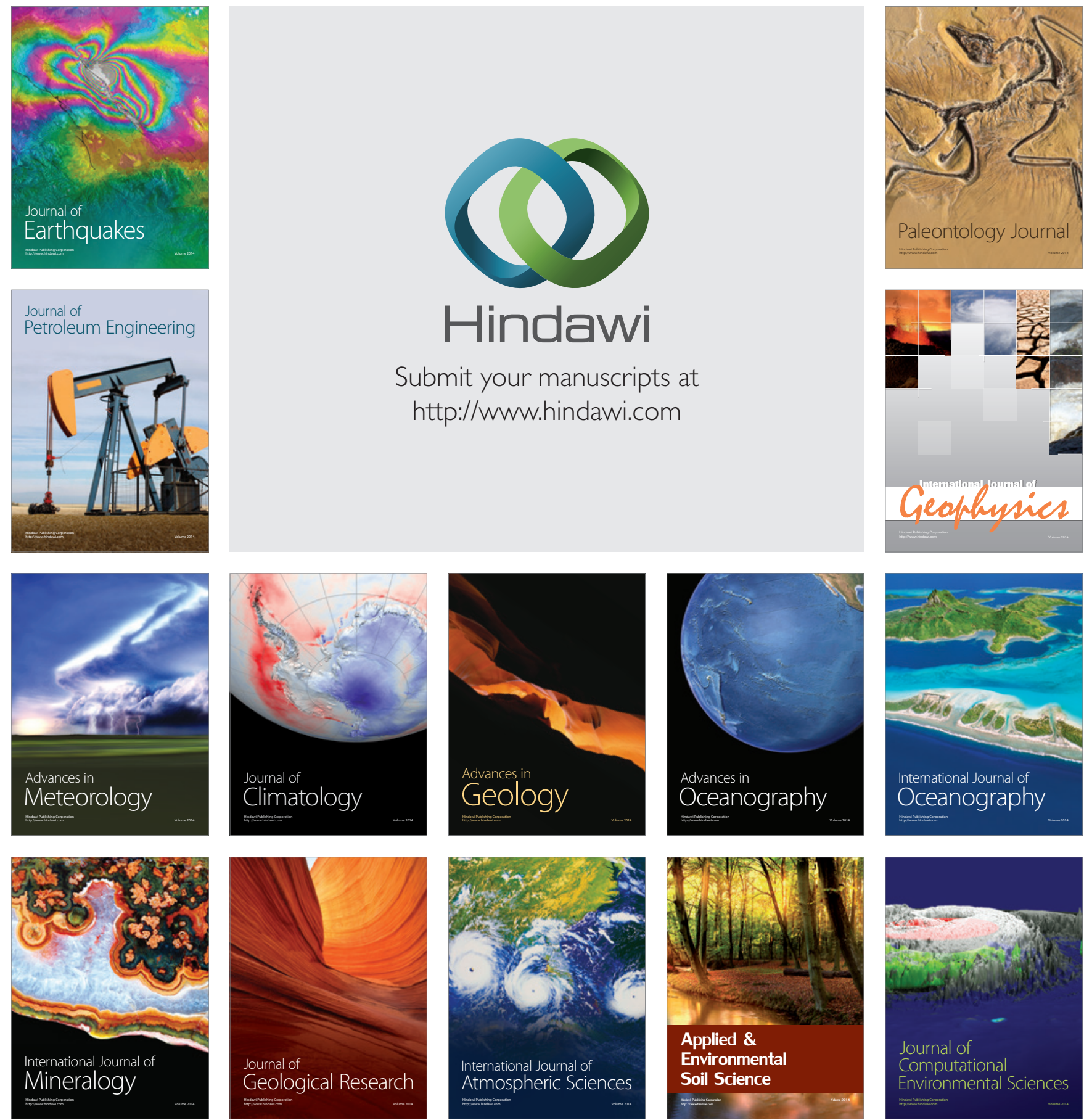